\title{
ADMINISTRATION OF ESTATES IN MALAYSIA: JURISDICTION AND MISCONCEPTION
}

\author{
Muhammad Amrullah Drs Nasrul \\ Ahmad Ibrahim Kulliyah of Laws, \\ International Islamic University Malaysia \\ E-mail: amrullah@gmail.com \\ Wan Noraini Mohd Salim \\ Ahmad Ibrahim Kulliyah of Laws, \\ International Islamic University Malaysia \\ E-mail: w.noraini@iium.edu.my \\ Muhamad Helmi Md Said \\ Ahmad Ibrahim Kulliyah of Laws, \\ International Islamic University Malaysia \\ E-mail: mhemisaid@gmail.com \\ Siti Nuramani Abdul Manap \\ Faculty of Law, Universiti Teknologi Mara \\ E-mail: nuramani@salam.uitm.edu.my
}

\begin{abstract}
The administration of estate formally commences upon the application by the beneficiaries to the related administrative bodies. The application marks the beginning step in the administration of estate since the application is an essential process in obtaining the letters of representation. With the existence of multiple administrative bodies in Malaysia, one needs to ensure that the application is made to the right administrative body. Furthermore, the administration of estate needs to be promptly settled to avoid any unwanted consequences, hence justifying the need for the early application by the beneficiaries. However, some beneficiaries deliberately stall the application, which is detrimental to the administration of estate. Confusion in identifying the right administrative body as well as the wrong perception of the beneficiaries of the administrative bodies have been identified as the causes behind the late application. This paper addressed the jurisdiction of the administrative bodies in the administration of the deceased's estate in Malaysia through
\end{abstract}


the comparative approach in classifying the different roles and authorities of each administrative body. The writing involved the research method by way of a library-based study whereby the data were collected from multiple sources including conference papers, textbooks, statutes, case laws, journals and other materials. The finding points out several suggestions including the need for collaboration between the society and the government in relaying the information regarding the actual impression of the administrative bodies in the administration of estate.

Keywords: Administration of estate, Administrative bodies, Letters of representation, Beneficiaries.

Abstrak: Pentadbiran harta pusaka bermula dengan permohonan oleh benefisiari terhadap badan-badan pentadbiran. Tindakan ini dianggap sebagai langkah permulaan dalam pentadbiran harta pusaka kerana ia merupakan proses utama dalam mendapatkan surat perwakilan. Dengan wujudnya beberapa badan pentadbiran di Malaysia, adalah perlu untuk memastikan bahawa permohonan itu dibuat terhadap badan pentadbiran yang betul. Selain itu, pentadbiran harta pusaka perlu diselesaikan dengan segera bagi mengelakkan sebarang akibat yang tidak diingini, dan ini menunjukkan bahawa perlunya sesuatu permohonan awal dilakukan oleh benefisiari. Walau bagaimanapun, terdapat sesetengah benefisiari yang sengaja melewatkan permohonan dan ini telah memberi kesan negatif terhadap pentadbiran harta pusaka. Kekeliruan dalam mengenal pasti badan pentadbiran yang betul serta persepsi negatif oleh benefisiari terhadap badan-badan pentadbiran merupakan antara punca di sebalik kelewatan dalam membuat permohonan terhadap pentadbiran harta pusaka. Artikel ini menjelaskan bidang kuasa badan-badan pentadbiran dalam pentadbiran harta pusaka di Malaysia melalui bentuk perbandingan dengan mengklasifikasikan peranan setiap badan pentadbiran. Penulisan ini melibatkan kaedah penyelidikan melalui kajian berasaskan perpustakaan di mana data dikumpulkan daripada pelbagai sumber termasuk kertas persidangan, buku teks, statut, kes undang-undang, jurnal serta bahan-bahan lain. Hasil penemuan daripada artikel ini antaranya menyentuh berkenaan cadangan perlunya kerjasama antara masyarakat yang kerajaan dalam menyampaikan maklumat tentang peranan sebenar badan-badan pentadbiran dalam pentadbiran harta pusaka. 
Kata kunci: Pentadbiran harta pusaka, Badan pentadbiran, Surat perwakilan, Benefisiari.

\section{INTRODUCTION}

Administration of estate is one of the integral parts in succession matter. It involves a process which deals with the deceased's estate in accordance with prescribed rules through a person who is authorised to manage the estate to its completion (Curzon, 2010). According to Halim (2012), administration of estate in its literal sense refers to the process of transferring the asset held by the deceased to the rightful beneficiaries or other interested parties. The technical definition given by Garner (2014), however, points out three main criteria in the administration of estate which include, (a) collection of the deceased's assets, (b) payment of debts and liabilities, and (c) distribution of the remainder of assets to those entitled. In other words, administration of estate does not only refer to the management and distribution of the asset owned by the deceased, but it also deals with the settlement of debts and liabilities which in priority ranks higher than the distribution of the assets.

The later definition also mentions the appointment of a particular person by the court to administer the deceased's estate. The court in this context, functions as an administrative body which is statutorily empowered in appointing the personal representative in dealing with the deceased's estate, be it testate or intestate cases (Halim \& Md Noor, 2015). In the Malaysian context however, the situation is rather different as the civil court is not the sole body granted with such authority. There are three administrative bodies in Malaysia which are involved in the administration of estate, each with separate jurisdictions. Apart from the civil High Court, the Estate Distribution Division and the Amanah Raya Berhad (ARB) undertake the role of administrative bodies which serve as a vital component in estate administration (Alma'amun, 2008).

It is through these bodies that the authority to deal with the deceased's estate legally is bestowed. Some of the administrative bodies possess additional functions over the others. The civil High Court, for instance, serves as a venue for dispute settlement through the litigation process. Amanah Raya Berhad, on the other hand, is 
authorised to act as a personal representative of the deceased's estate, especially in intestate cases. For the sake of this paper, however, the focus of the discussion will be limited to the authority of the administrative bodies in issuing the letters of representation to the applicant.

Despite having a different jurisdiction for each body, the existence of these multiple institutions unintentionally caused confusion among the public as to which administrative body they should approach. Unclear of the right institution to attend, the deceased's family members tend to stall the application, resulting in a delay of administration and distribution of the estate to the rightful beneficiaries. Such practice sometimes prolonged to years, incidentally leading to other unwanted implications.

\section{PUBLIC IMPRESSION REGARDING THE ADMINISTRATIVE BODIES}

The administration of estate has evolved from a practice which was originally based upon the local customary norm to a particular system under the influence of the English Common Law. From the introduction of the civil court system, such a system then gradually developed through time to give rise to other administrative bodies in charge of succession matter, which include the administration of estate (Noordin et al., 2012). Currently, the three administrative bodies govern the matter through separate jurisdiction. These multiple institutions aim to smoothen the process as well as make it easier for the public to handle the administration of estate which is known for its time consuming and challenging practice. Notwithstanding the similarities of the roles in administering the estates, the current existence of these institutions also led to a misperception among the public, especially in determining which administrative body they should seek to initiate the estate administration.

In practice, administration of estate formally begins with the application for letters of representation from the respective administrative bodies. However, it is important to note that there is a duty on part of the deceased's heir to commence with certain actions immediately after his death which include determining the asset of the deceased, identifying the beneficiaries as well as locating the 
related documents for the above application. Such application is usually done by the deceased's family members themselves, if not through other parties such as appointed solicitors. The latter would perhaps pose no difficulty as these solicitors are expected to possess expertise in succession matters, including determining the tasks and the appropriate administrative bodies under the administration of estate, whereas for the others, particularly the beneficiaries who are not familiar with the process of administration of estate, identifying which administrative body they should approach sometimes poses a problem due to the lack of knowledge regarding the differences between each administrative body.

Technically, there are four factors which determine the jurisdiction of the administrative bodies. The factors include (a) type of asset, (b) the value of the asset, (c) the state of the deceased as to whether the deceased dies testate or intestate and (d) the religious status of the deceased during his death. In focusing on the jurisdiction of the administrative bodies, the first and the second factors can further be divided into three categories, namely small estate, non-small estate and movable estate. Small estate refers to the type of asset comprising of solely immovable assets namely land and houses, or a combination of both immovable and movable assets where the valuation amounts to two million ringgit and below (Md Azmi \& Mohammad, 2014). Small estate falls under the jurisdiction of the Estate Distribution Division. Non-small estate generally refers to the same type of asset, but with the valuation of above two million ringgit and this category of asset falls under the jurisdiction of the civil High Court. Movable asset refers to other types of asset apart from land and houses. ARB possesses the jurisdiction in administering the movable asset where the value is below RM600, 000 where as the civil High Court confers jurisdiction on movable asset above RM600, 000.

\section{SUMMARY OF JURISDICTION OF THE ADMINISTRATIVE BODIES IN MALAYSIA}

\section{Civil High Court}

The High Court is the part of the civil court system which possesses an exclusive jurisdiction in succession matters as stated in Article 74, 
cross-referred to the Ninth Schedule of the Federal Constitution. The term "exclusive jurisdiction" implies that the estate administration of both Muslim and non-Muslim is under the jurisdiction of the civil High Court. As for Muslims, they are also subjected to the jurisdiction of the Syariah Court in succession matters, such as the determination of the validity of the will, identification of the heirs and distribution under fara' $i d$. In short, administration of estate involving Muslim subjects involves the participation of the civil High Court for the issuance of letters of representation and the Syariah Court for the issuance of fara'id certificate, namely.

The jurisdiction of the High Court is also determined by the value and types of asset. Technically, the High Court possesses jurisdiction in cases involving two categories of assets, namely (a) estates comprising of immovable or movable assets or a combination of immovable and movable assets where the value is more than two million ringgit, and (b) estates comprising of immovable or movable assets or a combination of immovable and movable assets where the value is less than two million ringgit, involving the deceased who died testate. Any value of asset outside these two categories will be subjected to the jurisdiction of the Estate Distribution Division or ARB accordingly.

There are two types of letters of representation which can be granted by the High Court, namely the Grant of Probate for testate cases and the Letter of Administration for intestate cases (Aziz et al., 2014). There are varieties of Letters of Administration, each subject to different situations. The application for the grant of the letters of representation by the High Court can be in the form of non-contentious and contentious probate proceedings. While a non-contentious probate proceeding involves a straightforward application process, a contentious probate proceeding generally involves court hearing sessions which usually take some time to complete the entire procedure.

\section{ESTATE DISTRIBUTION DIVISION}

Estate Distribution Division is a government agency which exclusively deals with the deceased's asset which falls under the 
category of a small estate. However, there is another factor which determines the jurisdiction of this administrative body, which is the state of the deceased. It is stated under Section 8 of the Small Estate (Distribution) Act 1955 that only intestate cases shall be handled by the Estate Distribution Division or the land administrator. The state of the deceased where he died testate or intestate further determines the jurisdiction of the administrative bodies. In this case, if the deceased died testate, that is, passed away leaving a valid will, the case must then be referred to the civil High Court, despite falling under the category of a small estate. This is stated under Section 5 of the said Act.

Reference to the Estate Distribution Division is made to apply for the Distribution Order or Letter of Administration. Under Section 8, the land administrator is authorized to issue the Distribution Order, labelled under the abbreviation of Form $\mathrm{E}$ in cases where the asset of the deceased is in transferable condition. In other words, the Distribution Order will only be issued if there are no issues with the asset which might prevent it from being transferred or distributed to the beneficiaries. Otherwise, the land administrator will issue a letter of administration where a person will be appointed as an administrator to resolve any matters related to the deceased's asset as stated under section 13(4) of the Act. For instance, in a case where the individual title to the deceased's land has yet to be issued, the land administrator will appoint an administrator to resolve this matter by issuing the letter of administration under form $\mathrm{F}$. Both orders may sometimes be issued simultaneously, depending on the case. For instance, both form $\mathrm{E}$ and form $\mathrm{F}$ will be issued simultaneously to enable the distribution of movable asset to be made, and at the same time appoint an administrator to resolve any unsettled matter.

There are several advantages of estate administration by the Estate Distribution Division. The first one is the fees charged are relatively cheap compared to the civil High Court and the ARB. In this case, an amount of 0.2 percent of the total value of the deceased asset will be charged as fees. As a government agency, the aim is to assist the public, especially the small and the middle-income class. In addition to this, several amendments have been made to increase the monetary jurisdiction of the Estate Distribution Division, since its establishment. The last amendment was made in 2009 to increase 
the jurisdiction from RM 600, 000 to two million ringgit which allows for a wider coverage of asset value (Shafie et al., 2014).

The second advantage is the non-requirement on the part of the applicant to produce the fara'id Certificate as the land administrator is capable of doing a fara'id calculation which then will be deduced from the letters of representation. For application at the civil High Court or ARB, the applicant is required to obtain the fara'id certificate as the document is required prior to the issuance of letters of representation (Halim \& Mohd Noor, 2015). However, the exclusion of issuing the fara'id certificate is subjected to the degree of the case. For example, if the case involves a complex calculation, usually those involving a series of deaths involving several generations of the beneficiaries, the land administrator will nevertheless request the applicant to initially obtain the fara'id certificate from the Syariah Court.

\section{Amanah Raya Berhad}

Amanah Raya Berhad (ARB) is another administrative body which is heavily involved in the administration of estate. Also known as the Corporation, ARB is a former government agency which now operates as a government-owned company, being privatised under the Public Trusts Corporation Act (1995). ARB is authorised to issue two administrative orders, namely the Letter of Declaration under Section 17(1) and the Letter of Direction under Section 17(2) of the same Act in cases involving movable assets whose value is below RM600, 000. A Letter of Direction is issued in cases where the asset value is below RM50, 000 whereas a Letter of Declaration involves assets that are valued above RM50, 000 but below RM600, 000 (Alma'amun, 2010). The Corporation is also empowered to act as the personal representative either in the testate or intestate cases. The role in administering the deceased's estate is a unique feature which is available only to the ARB and not to the other administrative bodies. In this aspect, the ARB is specifically assigned to administer the deceased's estate from the beginning until the end. It is the same practice which is offered by the solicitor or other trust companies which provide the service to the public which therefore, involves fees being charged for the service given. 


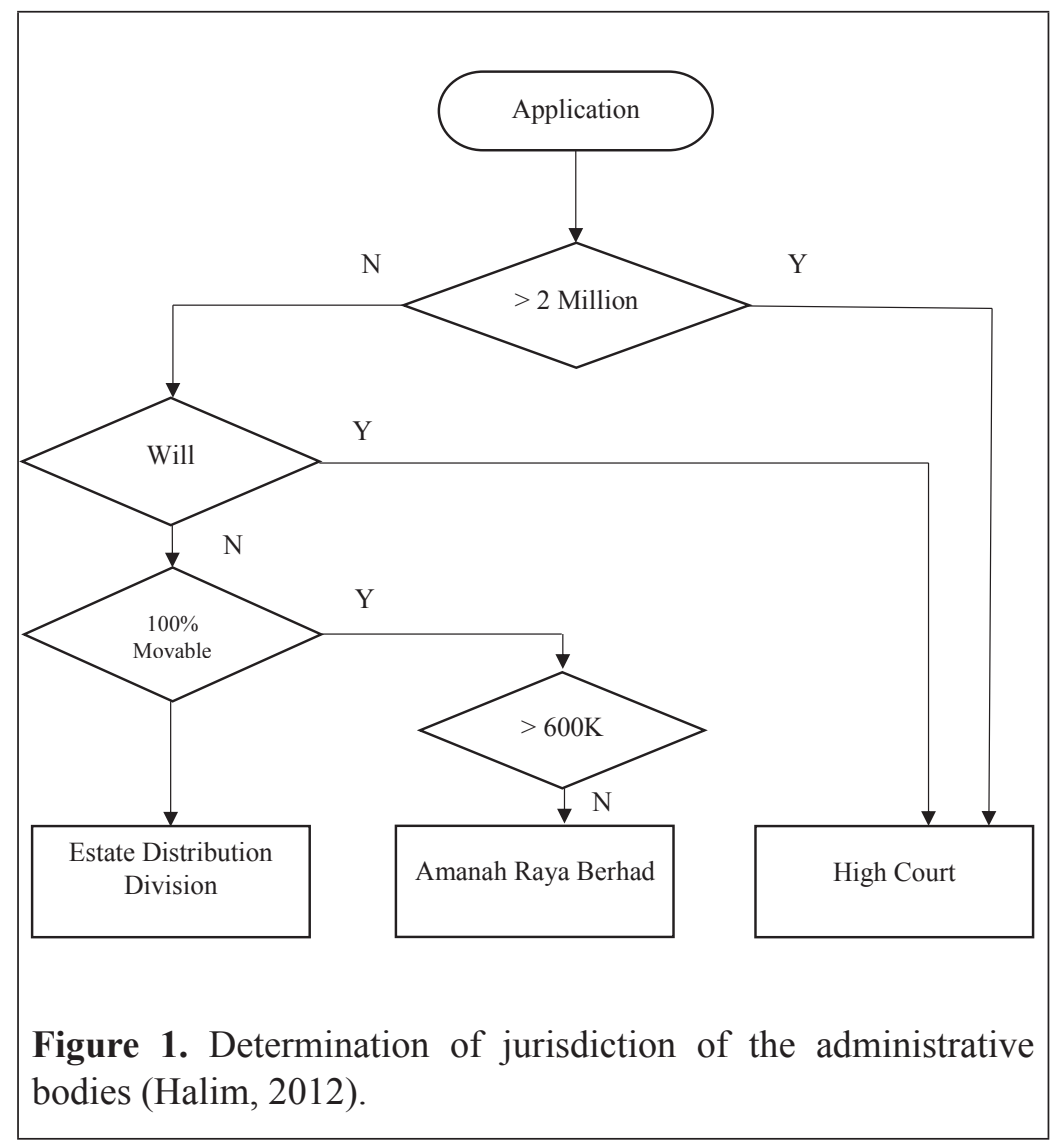

Therefore, it may lead to the misconception among the public that the ARB is overcharging its clients with hefty fees.

\section{CAUSES BEHIND THE MISCONCEPTION OF THE ADMINISTRATIVE BODIES}

Lack of knowledge has been identified as one of the primary causes behind the misconception among the public of the administrative bodies. This misconception relates to the ignorance of the public as to the existence of the administrative bodies notwithstanding their position and roles. Despite the easy means of obtaining information in the current era such as through the Internet, there are still those who do not realise the existence of these institutions; what more 
the differences between the administrative bodies. This makes it difficult to determine which administrative body they should approach to apply for letters of representation. As such, some of them decide to stall the application without taking the initiative to gather information regarding the matters.

Apart from this, ignorance relating to the process in the administration of estate is also regarded as the cause behind the misconception. Surprisingly, some people view the administrative bodies as unimportant and irrelevant as these people choose to handle the matter by themselves. They do not prefer any involvement from an outside party as they think that only the family members should manage the deceased's estate, thus ruling out the application for letters of representation to the administrative bodies (Salim, 2002). Difficulties arise when they start to realise that there are certain assets which require letters of representation because, without it, extraction, transfer or distribution of such asset cannot not take place.

Another cause leading to the misconception of the administrative bodies is the perception of the public regarding the status of these institutions. For instance, some people do not wish to initiate the application at the court as they are intimidated upon realising that they have to deal with the court for such matters. This is likely to happen to individuals who lack knowledge regarding the court's function, hence leading to unnecessary fear, be it towards the civil or the Syariah court. The idea that the court is a venue to solely deal to with crimes adds to this misconception. There are also those who do not understand the function of the Syariah Court in relation to fara 'id that the fara ' $i d$ certificate is important, not only for determining the beneficiaries and their entitled portions under fara' $i d$, but also as a supplementary document in applying for letters of representation. It is the lack of knowledge in fara'id itself that leads to such a misconception (Rashid et al., 2013; Shafie et al., 2014).

\section{IMPLICATIONS}

Misconception of the administrative bodies tends to cause delay in the administration of estate which ultimately hinders the beneficiaries 
from receiving their entitled portions from the asset distribution. Apart from this, there are also other adverse implications. Firstly, delaying the administration could lead to the death of the beneficiaries involving several generations. This makes it difficult to tracking the beneficiaries and their portions under fara 'id. Since the administration of estate now involves other generations of recipients, the process will take a long time to complete as the distribution and transfer of assets need to be made to the beneficiaries of an earlier generation, before proceeding to the later ones.

Secondly, a delay in starting the administration of estate also increases the risk of destruction or disappearance of the assets and relevant documents. One of the reasons behind the importance of immediate application for administration of estate is to ensure the deceased's asset is being distributed and transferred as soon as possible to avoid this complication. Loss of individual title deeds, for example, will prevent the transfer of land to the beneficiaries and to remedy such a problem will incur additional cost and time. For other types of asset, such as a vehicle, a delay in administration of estate will only decrease its value due to depreciation. Therefore, if the idea is to sell the vehicle, even a lapse of a few years will drastically reduce its value, which is a loss for the vehicle ownership certificate (VOC), should the transfer of ownership not take place within two years after the death of the original vehicle owner.

\section{SUGGESTIONS}

Despite the misconception of the public of the administrative bodies, it is to be noted that the purpose of the establishment of these multiple institutions is meant to provide easier access to the public in applying for letters of representation. Also, an institution such as the Estate Distribution Division offers a low-cost service which is affordable even to the low-income class. The misconception among the public may occur due to the variety of administrative bodies which can be remedied through the right means of solution. In response, this article offers two suggestions. The first one is to bolster the effort of spreading wide the information regarding the administrative bodies. Various means of relaying the information can be utilised either by taking advantage of the use of the media. 
Internet or even through conventional methods including forums, public dialogues and religious sermons. All these methods may be effective not only in relaying the information but also in erasing the misconception and scepticism of the public of the administrative bodies.

The second suggestion is to improve the current system for a better and easier access by the public to the service offered by the administrative bodies. An ongoing project in harmonising the jurisdiction of the administrative bodies is in process. The idea of establishing the one-stop centre is viewed as a great idea in providing a smoother process, particularly during the early stage of the administration of estate (Mahbar, 2016). This can avoid the misconception of the need to approach multiple administrative bodies at once, such as for Muslims who needs to obtain the fara'id certificate before applying for the letters of representation from another administrative body.The easy access in obtaining the related data from various agencies, could provide for a quick settlement of the administration of estate, hence negating any unnecessary delay in the distribution of the deceased's estate.

\section{REFERENCES}

Abdullah, M. A., Arifin, M., Omar, M. N., Napiah, M., \& Deen, M. (2012). Is a nominee a trustee or a beneficiary? A study on the Islamic legal maxim. In Contracts effect is given to intention and meaning and not words and forms and its relevance to the nomination concept and practice in the administration of a Muslim's estate in Malaysia. Australian Journal of Basic and Applied Sciences, 6(11), 153-159. Retrieved from http:// www.ajbasweb.com

Ahmad, M. Y., \& Ibrahim, I. A. (2002). Amalan penamaan harta orang Islam di Malaysia: Satu tinjauan ringkas menurut syariah Islamiah. Jurnal Pengajian Umum Bil, 3(6), 64. Retrieved from http://www.ukm.my/jmalim/index.

Alma'amun, S. (2008). Analysing the practice of Wasiyyah (Islamic Will) within AmRuthe contextual form of islamic estate planning in Malaysia: Variations across control 
variables. Development, 28-29. Retrieved from http://ibtra. com/journal_back_issue_individual.php?j_id $=22$

Alma'amun, S. (2010). Islamic estate planning: Malaysian experience. Kyoto Bulletin of Islamic Area Studies, 3(2), 165185. from http://hdl.handle.net/2433/123275

Aziz, A., Ridhwan, M., Nooh, M. N., Khairi, K. F., Johari, F., Mirza, I., \& Nordin, N. I. (2014). A review on literatures in planning and managing of islamic wealth distribution (2001-2013). Library Philosophy and Practice (e-journal). Paper 1144. Retrieved from http://digitalcommons.unl.edu/ libphilprac/1144

Curzon L.B. Dictionary of law (6 $6^{\text {th }}$ ed). International Law Book Services.

Garner, B. A. (2014). Black's law dictionary. West Group.

Federal Constitution. (1957).

Halim, A. H. (2012). Administration of estates in Malaysia: Law and procedure. Sweet \& Maxwell.

Halim, A. H., \& Mohd Noor, N. A. (2015). Personal representative cum trustee in estate administration: Conflict of duties and obligations. Retrieved from repo.uum.edu.my

Mahbar, S. (2016, September). Transformasi pengurusan pentadbiran harta pusaka di Malaysia: Cabaran dan penyelesaiannya. Paper presented at the Seminar Kebangsaan Transformasi Pengurusan Harta Pusaka, Malaysia.

Md Azmi, F. A., \& Sabit Mohammad, M. T. (2011). The causes of unclaimed, late claimed or distributed estates of deceased Muslims in Malaysia. In International Conference on Sociality and Economics Development, Vol. 10, 440-444. Retrieved from http://ipedr.com/list-35-1.html

Noordin, N., Shuib, A., Zainol, M. S., \& Adil, M. A. M. (2012). Preliminary time-based NFP model for heavy-tailed Islamic inheritance data. In International Conference on Statistics in Science, Business, and Engineering (ICSSBE), 1-6. Doi: 10.1109/ICSSBE.2012.6396588

Noordin, N., Shuib, A., Zainol, M. S., \& Adil, M. A. M. (2012). Review on issues and challenges in Islamic inheritance distribution in Malaysia. OIDA International Journal of Sustainable Development, 3(12), 27-38. Retrieved from https://papers.ssrn.com

Probate and Administration Act 1959. 
Public Trusts Corporation Act 1995.

Rashid, R. A., Hassan, S. A., \& Yaakub, N. I. (2013). A need for legal framework of gift inter vivos (Hibah) in Malaysian estate planning. International Journal of Business Economics and Law, 2(3), 29-31. Retrieved from http://ijbel.com/

Shafie, F., Yusoff, W., Zahari, W., Abdullah, S., \& al-Edrus, S. M. D. (2014). Islamic real estate management: Review on issues and challenges in managing inheritance property in Malaysia. Paper presented at the 7th International Real Estate Research Symposium 2014 (7th IRERS). Retrieved from http://www. inspen.gov.my/

Sitiris, M., \& Halim, A. H. (2010). Tuntutan harta sepencarian dalam kes kematian. Kanun-Jurnal Undang-Undang Malaysia, 22(1), 26-46. Retrieved from http://irep.iium.edu. my/3446/

Small Estates (Distribution) Act 1955.

Soalan lazim pusaka. Retrieved from http://www.arb.com.my /bm/ index

Wan Noraini Mohd Salim, Problems in the administration and distribution of intestate estate in Malaysia with special reference to its foundation in customary law, islamic law and English law, PhD Thesis, University of Exeter, United Kingdom, 2002.

What is administration of estates? (n.d). Retrieved February 20, from http://thelawdictionary.org

Wills Act1959. 